\title{
FAKTOR PENGARUH KEJADIAN KANKER SERVIKS DI YAYASAN KANKER WISNUWARDHANA SURABAYA TAHUN 2015
}

\author{
FACTOR EFFECT OF THE OCCURRENCE OF CERVICAL CANCER IN THE \\ YAYASAN KANKER WISNUWARDHANA SURABAYA 2015
}

\author{
Dessyar Patricia \\ Mahasiswa Departemen Biostatistika dan Kependudukan \\ RachmahIndawati \\ Dosen Departemen Biostatistika dan Kependudukan \\ Fakultas Kesehatan Masyarakat Universitas Airlangga \\ Jl. Mulyorejo Kampus C Unair Surabaya 60115 \\ Alamat korespondensi:Dessyar Patricia \\ E-mail: acik88@gmail.com
}

\begin{abstract}
Cervical cancer is one of the types of cancer that second deadliest only to breast cancer. Based on the World Health Organization, 490,000 women are diagnosed with cervical cancer and $80 \%$ of them are in developing countries. The factors that cause cervical cancer are age, age of first marriages, types of contraceptives, long-term use of contraceptives, number of children, and the Pap smear examination.

The purpose of this study is to determine the characteristics of patients in Surabaya Wisnuwardhana Cancer Foundation, to analyze the risk factors for women affected by cervical cancer by using odds ratios, and to analyze the factors that affect cervical cancer by using binary logistic regression analysis. Binary logistic regression analysis is used as the dependent variable in this study have two categories.

This type of observational study using cross sectional design. The population in this study is 1258 patients and samples taken from 303 by using simple random sampling. The dependent variable in this study is the state of the cervix and the independent variables are the pap smear examination, long-term use of contraceptives, age of first marriage, age, type of birth, and number of children.

The results of this study stated that the value of variable significance papsmear inspection visits, types of contraceptives, age of first marriage for $0,027,0,000$, and 0,000 , which means Ho rejected so that these variables affect the state of the cervix. Then it will be known to the prediction model, that is :
\end{abstract}

$$
f(z)=\frac{1}{1+e^{-(-0,900-0,640 \text { (visits) }+1,328 \text { (types of contraceptives)- 1,655 (age of first marriage) })}}
$$

Keywords:binary logistic regression, Cervical Cancer, risk factors 


\section{ABSTRAK}

Kanker serviks merupakan salah satu jenis kanker yang mematikan nomor dua setelah kanker payudara. Berdasarkan WHO, 490.000 perempuan didiagnosa terkena kanker serviks dan $80 \%$ berada di Negara berkembang. Faktor yang menjadi penyebab terjadinya kanker serviks adalah usia, usia pertama melakukan pernikahan, jenis alat kontrasepsi, lama pemakaian alat kontrasepsi, jumlah anak, dan pemeriksaan papsmear.

Tujuan dari penelitian ini adalah untuk mengetahui karakteristik pasien yang ada di Yayasan Kanker Wisnuwardhana Surabaya, lalu untuk menganalisis faktor risiko wanita yang terkena kanker serviks dengan menggunakan odds ratio, kemudian yang terakhir untuk menganalisis faktor yang mempengaruhi kanker serviks dengan menggunakan analisis regresi logistik biner. Analisis regresi logistic biner digunakan karena variabel dependen dalam penelitian ini memiliki dua kategori.

Jenis penelitian ini bersifat observasional dengan menggunakan desain cross sectional. Populasi dalam penelitian ini berjumlah 1258 pasien dan diambil sampel sebesar 303 dengan menggunakan cara simple random sampling. Variabel dependen dalam penelitian ini adalah keadaan serviks dan variabel independen yaitu pemeriksaan papsmear, lama pemakaian alat kontrasepsi, usia perkawinan pertama, Usia, jenis kontrasepsi, jumlah anak.

Hasil penelitian yang dilakukan menyatakan bahwa nilai signifikansi variabel kunjungan pemeriksaan papsmear, jenis alat kontrasepsi, usia perkawinan pertamasebesar $0,027,0,000$, dan 0,000 yang berarti Ho ditolak sehingga variabel tersebut berpengaruh terhadap keadaan serviks. Kemudian akandiketahuimodelprediksiyaitu :

$$
f(z)=\frac{1}{1+e^{-(-0,900-0,640 \text { (kunjungan) }+1,328 \text { (jenisKB)-1,655 (usiakawin)) }}}
$$

\section{Kata kunci: regresi logistik biner, kankerserviks, faktor risiko}

\section{PENDAHULUAN}

Kanker serviks atau biasa disebut dengan kanker leher rahim merupakan salah satu jenis kanker yang paling berbahaya yang diderita oleh wanita diatas usia 30 tahun. Kanker serviks adalah sejenis kanker yang 99,7\% disebabkan oleh human papilloma virus (HPV) onkogenik yang menyerang leher rahim. Penyakit ini banyak menyerang wanita yang memiliki banyak anak dan kurang menjaga kesehatan reproduksinya. Faktor yang paling mempengaruhi penularan virus ini adalah perilaku seseorang yang sering berganti pasangan seksual (Septadina, et al. (2015).

Kanker serviks merupakan penyakit yang mematikan dan merupakan jenis yang paling banyak ditemukan setelah kanker payudara. Berdasarkan WHO 490.000 perempuan didiagnosa terkena kanker serviks dan $80 \%$ berada di Negara berkembang termasuk Indonesia. Hal ini dikarenakan penderita kanker serviks datang ke tempat pelayanan kesehatan dengan kondisi yang sudah berada di stadium lanjut, dimana kanker sudah menyebar ke berbagai organ lain sehingga biaya yang dikeluarkan cukup banyak dan kondisi tubuh sudah semakin parah yang menyebabkan angka kematian semakin tinggi. Sekitar $90-95 \%$ faktor risiko penyakit ini berhubungan dengan perilaku seseorang dalam menjaga kesehatannya dan juga lingkungan disekitar (Septadina, et al. (2015).

Faktor yang menyebabkan terjadinya kanker serviks dapat berasal dari berbagai macam sebab. Semua wanita berisiko untuk terserang kanker serviks, namun beberapa faktor risiko yang dapat meningkatkan peluang terjadinya kanker serviks antara lain umur, wanita yang berumur 35-50 tahun dan masih aktif berhubungan seksual yang rawan terserang kanker serviks. Umur pertama kali berhubungan seksual juga merupakan faktor terjadinya kanker serviks. Sekitar 20\% kanker serviks dijumpai pada wanita yang aktif berhubungan seksual sebelum umur 16 tahun (Wahyuningsih dan Mulyani, 2014).

Kanker serviks juga dapat diakibatkan oleh lama pemakaian alat kontrasepsi. 
Berdasarkan hasil penelitian menyebutkan bahwa mayoritas ibu dengan lama penggunaan alat kontrasepsi kurang dari 5 tahun lebih berisiko terkena kanker serviks daripada ibu dengan lama penggunaan alat kontrasepsi lebih dari 5 tahun (Rejeki dan Istiana, 2015). Didukung dengan hasil penelitian lain yang menyatakan bahwa ada hubungan antara pemakaian alat kontrasepsi hormonal kurang dari 3 tahun dengan kejadian prakanker serviks $(78,6 \%)$ (Lestari, 2009).

Faktor risiko lain selain usia dan lama penggunaan alat kontrasepsi adalah usia perkawinan pertama. Ibu yang melakukan perkawinan pertama kali pada usia 20-24 tahun adalah yang terbanyak menderita kanker serviks sebanyak 19 kasus dari 40 kasus. Sedangkan kelompok usia 15-19 tahun kedua terbanyak menderita kanker serviks. Hal ini membuktikan bahwa usia perkawinan pertama dibawah 20 tahun menyebabkan risiko lebih besar terkena kanker serviks (Lasut, et al. 2015).

Selain itu faktor risiko lain adalah jumlah anak yang dilahirkan juga menjadi penyebab terjadinya kanker serviks. Hasil penelitian lain yang telah dilakukan menyatakan bahwa penderita kanker serviks terbanyak dengan paritas 3-5 (Prandana dan Rusda, 2013). Didukung dengan penelitian lain yang menyatakan penderita kanker serviks terbanyak terdapat pada pasien dengan jumlah anak lebih dari 6 (Aida, 2003). Seseorang yang sering melahirkan (banyak anak) apalagi dengan jarak kelahiran yang pendek termasuk orang yang memiliki risiko besar terkena kanker serviks (Prandana danRusda, 2013).

Kejadian kanker serviks sebenarnya dapat dikendalikan dengan berbagai macam pencegahan primer seperti menerapkan pola hidup bersih dan sehat, melakukan imunisasi vaksin HPV dan juga melakukan pencegahan dini dengan mengikuti papsmear. Dengan adanya deteksi dini diharapkan angka kematian yang disebabkan oleh kanker serviks dapat berkurang. Hal ini tentunya membutuhkan kesadaran masyarakat itu sendiri untuk sadar akan kesehatannya karena rata-rata penyakit ini tidak ada gejala di awal dan masyarakat cenderung memeriksa saat stadium lanjut.

Perkembangan dunia yang semakin pesat juga diikuti dengan banyaknya permasalahan yang semakin kompleks menjadi motivasi untuk mengembangkan ilmu pengetahuan guna mencari solusi dan mengambil keputusan dalam masalah yang dihadapi sehari-hari. Analisis statistik dibutuhkan untuk menjadi salah satu alternatif dalam mengambil suatu keputusan yang rasional dan ilmiah berdasarkan data historis yang ada. Selain itu, analisis statistik dapat mengolah datadata yang ada untuk digunakan sebagai bahan pengambilan keputusan yang strategis. (Asyiah, 2008).

Banyaknya ilmu statistik terapan yang dikembangkan menyebabkan penemuanpenemuan baru dalam menganalisis suatu masalah. Salah satu analisis yang dapat digunakan untuk menganalisis suatu masalah adalah analisis dengan menggunakan metode regresi logistik. Regresi logistik merupakan sebuah metode yang digunakan untuk melihat adanya pengaruh antara dua atau lebih variabel. Regresi logistik mempunyai dua variabel yaitu variabel independen (bebas) dan variabel dependen (terikat). Variabel independen adalah variabel yang mempengaruhi atau yang menjadi sebab perubahan atau timbulnya variabel dependen. Sedangkan untuk variabel dependen merupakan variabel yang dipengaruhi atau yang menjadi akibat karena adanya variabel bebas (Sugiyono, 2009).

Analisis regresi logistik dapat dikelompokkan menjadi dua macam berdasarkan variabel independen nya yaitu analisis regresi logistik sederhana dan analisis regresi logistik berganda. Analisis regresi logistik sederhana digunakan untuk menganalisis hubungan antara variabel dependen (terikat) dengan satu variabel independen (bebas). Sedangkan untuk analisis regresi logistik berganda digunakan untuk melihat hubungan antara variabel dependen dengan variabel independen yang lebih dari satu. Jika dilihat dari variabel dependen nya maka regresi logistik 
dibedakan menjadi dua yaitu regresi logistik biner yang hanya mempunyai dua kategori pada variabel dependen nya dan regresi logistik multinomial yang mempunyai dua atau lebih kategori (Albana, 2013).

Regresi logistik banyak digunakan dalam bidang kesehatan karena sering kali suatu penelitian ingin melihat fenomena dengan variabel dependen yang bersifat dikotomus yang artinya hanya memiliki dua kemungkinan yaitu ya dan atau tidak. Alasan utama regresi logistik sering digunakan adalah rumus logistik $\mathrm{f}(\mathrm{z})$ yang terletak antara 0 dan 1 , model ini didesain untuk mendeskripsikan atau menggambarkan kemungkinan (probabilitas). Dalam hal epidemiologi probabilitas seperti itu memberikan informasi risiko seorang individu terkena suatu penyakit. Karena itu apapun estimasi dari risiko yang didapat akan selalu diantara 0 dan 1. Model logistik tidak pernah mendapat estimasi risiko dibawah 0 dan diatas 1. Hal ini tidak selalu sesuai untuk kemungkinan model lain, oleh karena itu model logistik sering menjadi pilihan pertama ketika probabilitas akan diperkirakan (Kleinbaum, 2010).

Alasan lain uji regresi logistik sering digunakan adalah berhubungan dengan fungsi logistik. Dimulai dari $Z=-\infty$ dan berpindah ke kanan, maka nilai $Z$ naik, nilai dari $\mathrm{f}(\mathrm{z})$ mendekati 0 untuk sementara, lalu mulai naik kearah 1 dan akhirnya berada di sekitar nilai 1. Hal ini menghasilkan fungsi logistik yang berbentuk $\mathrm{S}$ dan memanjang. Bentuk $\mathrm{S}$ yang menarik menggambarkan gabungan efek dari berbagai faktor risiko terhadap faktor suatu penyakit (Kleinbaum, 2010).

Salah satu ukuran yang digunakan untuk menginterpretasikan koefisien variabel prediktor adalah odds ratio (OR). Odds ratio menunjukkan perbandingan peluang munculnya suatu kejadian dengan peluang tidak munculnya kejadian tersebut. Pada regresi logistik odds ratio dapat menghasilkan sebuah hasil jika OR $=1$ maka artinya paparan yang ada tidak mempengaruhi hasil (suatu penyakit). Jika OR $>1$, artinya paparan mempunyai peluang besar untuk mempengaruhi hasil. Sedangkan jika OR $<1$, artinya paparan mempunyai peluang kecil terhadap hasil (Novianti, 2012).

\section{METODE PENELITIAN}

Jenis penelitian ini bersifat observasional karena tidak melakukan intervensi terhadap subjek yang diteliti. Bertujuan untuk memberikan gambaran dan penjelasan terkait dengan pengaruh antar variabel. Penelitian ini dilakukan dengan mengukur variabel penelitian yang ada di catatan rekam medis dan kartu status pasien. Desain penelitian ini menggunakan desain cross sectional karena dilakukan pada waktu tertentu dan digunakan untuk menggambarkan suatu kegiatan atau keadaan dalam waktu tertentu. Selain itu semua data terkait dengan variabel nya dikumpulkan dalam waktu yang bersamaan.

Populasi dalam penelitian ini adalah semua wanita yang melakukan pemeriksaan papsmear di Yayayasan Kanker Wisnuwardhana Surabaya.Sampel yang digunakan dalam penelitian ini adalah wanita yang melakukan pemeriksaan papsmear di Yayasan Kanker Wisnuwardhana Surabaya dan didapat dari jumlah populasi.

Sampel dalam penelitian ini diambil dari perhitungan dengan rumus simple random sampling yaitu : $n=\frac{\mathrm{Npq}}{(N-1) D+p q}$ pada populasi sebesar 1258 pasien, diperoleh sampel sebagai berikut $n=$

$$
\begin{aligned}
\frac{\mathrm{Npq}}{(N-1) D+p q} & =\frac{1257 \times 0,5 \times 0,5}{(1257-1) \frac{B^{2}}{4}+0,5 \times 0,5} \\
& =\frac{314,25}{(1256) \frac{0,05^{2}}{4}+0,25} \\
& =\frac{314,5}{1,035}=303 .
\end{aligned}
$$

Cara penentuan dan pengambilan sampel menggunakan metode simple random sampling yaitu semua populasi memiliki kesempatan untuk menjadi sampel pada penelitian. Dengan perhitungan rumus simple random sampling diperoleh sampel sebesar 303 pasien. Pengambilan sampel dilakukan dengan menggunakan aplikasi SPSS yang mengambil sampel secara acak. Cara menentukan besar sampel dengan cara memasukkan seluruh jumlah populasi 
sebesar 1258 ke dalam SPSS kemudian melakukan pemilihan sampel yang nantinya diambil angka yang tidak dicoret dalam SPSS.

Analisis data dilakukan dengan menggunakan analisis regresi logistik biner untuk melihat pengaruh yang ditimbulkan oleh variabel independen terhadap variabel dependen. Analisis regresi logistik biner dipilih karena variabel independen yang lebih dari dua dan variabel dependen yang bersifat dikotomus atau memiliki 2 kategori. Selain menganalisis dengan menggunakan regresi logistik biner untuk melihat pengaruh, juga akan dilakukan analisis untuk melihat faktor risiko terjadinya kanker serviks dengan menggunakan odds ratio yang nantinya akan dicari pada setiap variabel independen untuk mengetahui faktor mana yang paling berpeluang dapat menyebabkan kanker serviks. Analisis dilakukan dengan SPSS.

Data yang telah dikumpulkan diolah dengan menggunakan excel untuk mengelompokkan menjadi 3 kelompok keadaan serviks yaitu tenang, erosi, dan ganas, kemudian data dianalisis dengan menggunakan SPSS. Langkah awal yaitu:

1. Analisis Bivariat, untuk mengetahui ada tidaknya hubungan antara variabel independen dengan variabel independen dengan menggunakan uji Chi Square. Untuk menentukan kemaknaan hasil perhitungan statistik digunakan batas kemaknaan 0,05. Dengan demikian jika $\mathrm{p}$ value $<0,05$ maka hasil perhitungan secara statistik bermakna dan jika $\mathrm{p} \geq$ 0,05 maka hasil perhitungan statistik tidak bermakna.

2. Analisis regresi logistik, dilakukan untuk melihat variabel independen mana yang mempunyai pengaruh terhadap variabel dependen dan membuat suatu model prediksi. Langkah-langkah analisis regresi logistik sebagai berikut:

a. Uji signifikansi model dengan melihat signifikansi pada tabel Omnibus Tests of Model Coefficients.

b. Uji kesesuaian model melihat nilai signifikansi pada tabel Hosmer and Lemeshow c. Uji parsial dan pembentukan model. Uji parsial dapat dilihat berdasarkan nilai signifikansi masing-masing variabel pada tabel variables in the equation untuk melihat apakah variabel independen berpengaruh pada variabel dependen. Setelah itu membentuk model regresi logistic biner.

d. Intepretasi odds ratio melihat pada kolom $\operatorname{Exp}(B)$.

\section{HASIL PENELITIAN DAN PEMBAHASAN}

Populasi pada kategori keadaan serviks tenang sebesar 824 pasien, keadaan serviks erosi sebesar 400 pasien dan keadaan serviks ganas sebanyak 34 pasien. Dari populasi tersebut diambil sampel dengan perhitungan simple random sampling dan didapatkan jumlah sampel sebesar 303 pasien dengan rincian pasien dengan keadaan tenang sebanyak 194 pasien, keadaan serviks erosi sebanyak 101 pasien, dan keadaan serviks ganas sebanyak 8 pasien. Karena jumlah pasien dengan kategori ganas sebanyak 8 maka dilakukan penggabungan jumlah antara pasien dengan kategori ganas dan kategorierosi.

Tabel 1. Hasil Pemeriksaan Papsmear di YayasanKanker Wisnuwardhana Surabaya

\begin{tabular}{lll}
\hline Hasil Pemeriksaan & Frekuensi & \multicolumn{1}{c}{$\%$} \\
\hline Tenang & 194 & 64,0 \\
Erosi & 101 & 33,3 \\
\hline Ganas & 8 & 2,6 \\
\hline Total & 303 & 100 \\
\hline
\end{tabular}

Wanita yang melakukan pemeriksaan papsmear di yayasan kanker wisnuwardhana Surabaya terdeteksi tenang sebanyak 194 pasien (64,0\%), terdeteksi erosi sebanyak 101 pasien $(33,3 \%)$, sedangkan terdeteksi ganas sebanyak 8 pasien $(2,6 \%)$.

Tabel 2. Hasil Kunjungan di Yayasan Kanker Wisnuwardhana Surabaya.

\begin{tabular}{lll}
\hline $\begin{array}{c}\text { Kunjunganpemeriksa } \\
\text { an }\end{array}$ & Frekuensi & \% \\
\hline Lama & 137 & 45,2 \\
Baru & 166 & 54,8 \\
\hline Total & 303 & 100 \\
\hline
\end{tabular}


Kunjungan dibagi menjadi 2 yaitu kunjungan lama dan kunjungan baru, dimana kunjungan lama pasien sebanyak 137 pasien $(45,2 \%)$ sedangkan pasien yang baru melakukan kunjungan sebanyak 166 pasien $(54,8 \%)$.

Tabel 3. Hasil Lama Pemakaian Alat Kontrasepsi di Yayasan Kanker Wisnuwardhana Surabaya

\begin{tabular}{cll}
\hline Lama KB & Frekuensi & $\%$ \\
\hline$>\mathbf{5}$ Tahun & 113 & 37,3 \\
$\leq \mathbf{5}$ Tahun & 190 & 62,7 \\
\hline Total & 303 & 100 \\
\hline
\end{tabular}

Lama pemakaian alat kontrasepsi dengan waktu $>5$ tahun sebanyak 113 pasien $(37,3 \%)$ sedangkan sisanya yaitu 190 pasien $(62,7 \%)$ menggunakan alat kontrasepsi dengan waktu $\leq 5$ tahun.

Tabel 4. Hasil Usia Perkawinan Pertama di Yayasan Kanker Wisnuwardhana Surabaya

\begin{tabular}{|c|c|c|}
\hline $\begin{array}{c}\text { Usia Perkawinan } \\
\text { Pertama } \\
\end{array}$ & Frekuensi & $\%$ \\
\hline$>22$ Tahun & 142 & 46,9 \\
\hline$\leq 22$ Tahun & 161 & 53,1 \\
\hline Total & 303 & 100 \\
\hline
\end{tabular}

Usia perkawinan pertama yang dilakukan pasien sebanyak 142 pasien (46,9\%) melakukan pada usia $>22$ tahun. Sedangkan pada usia $\leq 22$ tahun sebanyak 161 pasien $(53,1 \%)$.

Tabel 5. Hasil Usia Pasien di Yayasan Kanker Wisnuwardhana Surabaya

\begin{tabular}{ccc}
\hline UsiaPasien & Frekuensi & $\mathbf{\%}$ \\
\hline$>$ 40 Tahun & 144 & 47,5 \\
$\leq \mathbf{4 0}$ Tahun & 159 & 52,5 \\
\hline Total & 303 & 100 \\
\hline
\end{tabular}

Usia pasien yang memeriksakan diri $>$ 40 tahun sebanyak 144 pasien $(47,5 \%)$ sedangkan untuk pasien $\leq 40$ tahun sebanyak 159 pasien $(52,5 \%)$.

Tabel 6. Hasil Jenis Alat Kontrasepsi di YayasanKanker Wisnuwardhana Surabaya

\begin{tabular}{ccc}
\hline Jenis KB & Frekuensi & \% \\
\hline Hormonal & 229 & 75,6 \\
Non Hormonal & 74 & 24,4 \\
\hline Total & 303 & 100 \\
\hline
\end{tabular}

Pasien yang menggunakan alat kontrasepsi berjenis hormonal sebanyak 229 pasien $(75,6)$. Sedangkan yang memakai jenis alat kontrasepsi non hormonal sebanyak 74 pasien $(24,4 \%)$.

Tabel 7. Hasil Jumlah anak di Yayasan KankerWisnuwardhana Surabaya

\begin{tabular}{ccc}
\hline JumlahAnak & Frekuensi & $\mathbf{\%}$ \\
\hline >2 Anak & 119 & 39,3 \\
$\leq \mathbf{2}$ Anak & 184 & 60,7 \\
\hline Total & 303 & 100 \\
\hline
\end{tabular}

Pasien yang memiliki jumlah anak $>2$ anak sebanyak 119 pasien (39,3\%) sedangkan pasien yang memiliki jumlah anak $\leq 2$ anak sebanyak 184 pasien $(60,7 \%)$.

\section{Analisis Faktor Yang Mempengaruhi Kejadian Kanker Serviks}

Klasifikasi berdasarkan faktor apa saja yang mempengaruhi kanker serviks dapat dianalisis dengan menggunakan regresi logistik biner karena variabel dependen yang mempunyai 2 kategori (tenang, erosi). Kategori kanker serviks pada awalnya memiliki 3 kategori, namun karena jumlah dari kategori ganas sangat sedikit untuk dapat dianalisis, maka dilakukan penggabungan antara kategori erosi dan ganas sehingga terbagi menjadi 2 kategori. Variabel independen yang telah ditentutan untuk dapat dianalisis dalam model adalah usia pasien, umur perkawinan pertama, jumlah anak, kunjungan pemeriksaan papsmear, jenis alat kontrasepsi, dan lama penggunaan alat kontrasepsi. Langkah awal yaitu melakukan uji independensi. 
Tabel 8.Hasil Uji Independensi

\begin{tabular}{lcl}
\hline \multicolumn{1}{c}{ Variabel } & Asym. Sig. (2-sided) & Signifikansi \\
\hline Kankerserviks*Kunjungan & 0,003 & Signifikan \\
\hline Kankerserviks*Jenis KB & 0,000 & Signifikan \\
\hline Kankerserviks*Jumlahanak & 0,658 & Tidak signifikan \\
\hline Kankerserviks*Lama KB & 0,512 & Tidak signifikan \\
\hline Kankerserviks*UsiaKawinPertama & 0,000 & Signifikan \\
\hline Kankerserviks*Usiapasien & 0,061 & Tidak signifikan \\
\hline
\end{tabular}

Hasil uji independensi dari keenam variabel tersebut menjelaskan bahwa terdapat 3 variabel yang signifikan yaitu kunjungan pemeriksaan papsmear $(0,003)$, jenis alat kontrasepsi yang digunakan $(0,000)$, dan usia kawin pertama $(0,000)$. Sedangkan untuk 3 variabel lainnya tidak signifikan yaitu jumlah anak $(0,658)$, Lama pemakaian alat kontrasepsi $(0,512)$, dan usia pasien $(0,061)$.

Langkah selanjutnya yaitu uji signifikansi model yang dapat dilihat dari tabel Omnibus Tests of Model Coefficients.

Tabel 9 Hasil Uji Signifikansi Model

\begin{tabular}{lccc}
\hline \multicolumn{4}{c}{ Omnibus Test of Model Coefficients } \\
\hline & Chi-Square & df & Sig. \\
\hline $\begin{array}{l}\text { Step 1 } \\
\text { Step }\end{array}$ & 66,342 & 6 & 0,000 \\
\hline Block & 66,342 & 6 & 0,000 \\
\hline Model & 66,342 & 6 & 0,000 \\
\hline
\end{tabular}

Ho : Tidak ada variabel bebas yang signifikan mempengaruhi variabel respon.

H1 : Minimal ada satu variabel bebas yang signifikan mempengaruhi variabel respon.

Berdasarkan output omnibus test diatas dapat dilihat nilai sig $=0,000<\alpha=0,05$, berarti Ho ditolak yang artinya minimal ada satu variabel bebas yang signifikan mempengaruhi variabel respon. Berdasarkan hasil tersebut maka dapat disimpulkan bahwa model dapat digunakan untuk analisis lebih lanjut.

Kemudian langkah selanjutnya yaitu uji kesesuaian model dengan melihat hasil signifikansi pada tabel Hosmer and Lemeshow. Berikut merupakan hasil dari uji kesesuaian model :
Tabel 10 Uji Kesesuaian Model

\begin{tabular}{cccc}
\hline \multicolumn{4}{c}{ Hosmer and Lemeshow Test } \\
\hline Step & Chi-Square & df & Sig. \\
\hline 1 & 5,628 & 8 & .689 \\
\hline
\end{tabular}

Ho:Tidak terdapat perbedaan yang signifikan antara hasil pengamatan dengan kemungkinan hasil prediksi model.

H1 : Terdapat perbedaan yang signifikan antara hasil pengamatan dengan kemungkinan hasil prediksi model.

Berdasarkan output tabel Hosmer and Lemeshowdiketahui bahwa nilai signifikansi $=0,689>\alpha=0,05$, berarti Ho diterima, yang artinya Tidak terdapat perbedaan yang signifikan antara hasil pengamatan dengan kemungkinan hasil prediksi model atau model yang diperoleh sesuai (fit) dengan data dan dapat atau layak diintepretasikan. 
Tabel 11.Hasil Ketepatan Model

\begin{tabular}{|c|c|c|c|c|}
\hline & \multicolumn{4}{|c|}{ Prediksi } \\
\hline & \multicolumn{3}{|c|}{ Keadaan Serviks } & \multirow[t]{2}{*}{ Percentage Correc } \\
\hline & & Tenang & Erosi & \\
\hline \multirow{3}{*}{ Observasi } & Tenang & 160 & 34 & 82,5 \\
\hline & Erosi & 51 & 58 & 53,2 \\
\hline & $\begin{array}{c}\text { Overall } \\
\text { Percentage }\end{array}$ & & & 71,9 \\
\hline
\end{tabular}

Kemudian berdasarkan tabel diatas dapat disimpulkan bawa jumlah sampel yang tidak terkena kanker serviks (tenang) $160+$ $34=194$ orang dengan keterangan bahwa orang yang tidak terkena kanker serviks (tenang) sebanyak 160 orang dan yang seharusnya tidak terkena kanker serviks tetapi mengalami peradangan (erosi) sebanyak 34 orang. Sedangkan jumlah sampel yang mengalami peradangan (erosi)
$51+58=109$ orang dengan keterangan bahwa orang yang mengalami peradangan (erosi) sebanyak 58 orang dan yang seharusnya mengalami peradangan (erosi) namun tidak terkena kanker serviks (tenang) sebanyak 51 orang. Tabel di atas memberikan nilai overall percentage sebesar $71,9 \%$ yang berarti ketepatan model penelitian ini adalah sebesar $71,9 \%$.

Tabel 12.Hasil Pengaruh Variabel Independen Terhadap Variabel Dependen

\begin{tabular}{lrrrrrl}
\hline Variabel & B & S.E. & \multicolumn{1}{c}{ Wald } & df & Sig. & Ket \\
\hline Kunjungan & .640 & .289 & 4.890 & 1 & .027 & Signifikan \\
\hline Jenis KB & 1.328 & .377 & 12.397 & 1 & .000 & Signifikan \\
\hline Lama KB & .057 & .296 & .037 & 1 & .848 & Tidak Signifikan \\
\hline Usia Kawin Pertama & 1.655 & .287 & 33.155 & 1 & .000 & Signifikan \\
\hline Usia Pasien & .216 & .317 & .467 & 1 & .494 & Tidak Signifikan \\
\hline Jumlah Anak & .174 & .302 & .331 & 1 & .565 & Tidak Signifikan \\
\hline
\end{tabular}

Ho : Tidak terdapat pengaruh yang signifikan antara variabel dependen dan variabel independen.

H1 : Terdapat pengaruh yang signifikan antara variabel dependen dan variabel independen.

Pada tabeldiatas dapat dilihat bahwa variabel kunjungan pemeriksaan papsmearmemiliki nilai sig $=0,021<0,05$ berarti Ho ditolak sehingga kunjungan pemeriksaan papsmear mempunyai pengaruh yang signifikan terhadap keadaan serviks.

Kemudian nilai signifikansi pada variabel jenis alat kontrasepsi $=0,000<$ 0,05 artinya Ho ditolak sehingga jenis alat kontrasepsi memiliki pengaruh yang signifikan terhadap keadaan serviks.

Lama pemakaian alat kontrasepsi memiliki nilai sig $=0,848>0,05$ artinya Ho diterima jadi lama pemakaian alat kontrasepsi tidak mempunyai pengaruh terhadap keadaan serviks.

Nilai signifikansi pada usia perkawinan pertama sebesar $0,000<0,05$ yang artinya Ho ditolak sehingga usia perkawinan pertama memiliki pengaruh yang signifikan terhadap keadaan serviks.

Usia pasien mempunyai nilai signifikansi $0,494>0,05$ artinya $\mathrm{Ho}$ diterima sehingga usia pasien tidak mempunyai pengaruh terhadap keadaan serviks.

Nilai signifikansi pada variabel jumlah anak sebesar 0,565 >0,05 artinya Ho diterima sehingga jumlah anak tidak berpengaruh terhadap keadaan serviks.

Berdasarkannilai-nilai B padaperhitungan di atas, maka model persamaan yang dibentuk adalah sebagai berikut : 


$$
f(z)=\frac{1}{1+e^{-(-3,252+0,640 \text { (kunjungan) }+1,328 \text { (jenisKB)+ 1,655 (usiakawin)) }}}
$$

\section{PEMBAHASAN}

\section{Hubungan Antara Pemeriksaan Papsmear dengan Kejadian Kanker Serviks}

Hasil penelitian mengenai hubungan antara pemeriksaan papsmear dengan kejadian kanker serviks menunjukkan nilai $p=0,027$. Sehingga dapat disimpulkan bahwa Ho ditolak yang artinya ada pengaruh yang signifikan antara kunjungan pemeriksaan papsmear dengan kejadian kanker serviks. Hasil tersebut berdasarkan 109 pasien dari 303 pasien yang terkena peradangan (erosi) dimana mayoritas pasien yang memiliki kunjungan baru sebanyak 166 pasien.

Kunjungan pemeriksaan papsmear berpengaruh terhadap kejadian kanker serviks. Hal ini didukung oleh penelitian yang dilakukan oleh (Setyaningsih, et al. 2014) yang meneliti tentang tingkat pengetahuan tentang kanker serviks dengan motivasi melakukan pemeriksaan papsmear pada ibu rumah tangga. Dalam penelitian tersebut menyatakan bahwa ada hubungan antara tingkat pengetahuan tentang kanker serviks dengan motivasi melakukan pemeriksaan papsmear. berdasarkan penjelasan tersebut dapat diketahui bahwa kunjungan pemeriksaan papsmear yang berpengaruh terhadap kejadian kanker serviks juga dipengaruhi oleh pengetahuan seseorang itu sendiri terhadap kanker serviks.

Pemeriksaan papsmear yang dapat berpengaruh terhadap kejadian kanker serviks ternyata juga dipengaruhi oleh penyuluhan dan pemberian leaflet kepada ibu yang berisiko. Penyuluhan ini terbukti dapat mempengaruhi minat untuk melakukan pemeriksaan papsmear, berdasarkan penelitian menunjukkan adanya peningkatan minat sebelum diberikan penyuluhan dengan sesudah diberi penyuluhan. Terdapat peningkatan minat yang cukup baik dimana yang awalnya responden tidak berminat dan berminat sedang menjadi berminat tinggi untuk melakukan pemeriksaan papsmear (Herfanda dan Anjarwati, 2010)

Hubungan Antara Lama Pemakaian Alat Kontrasepsi dengan Kejadian Kanker Serviks

Hasil penelitian mengenai hubungan antara lama pemakaian alat kontrasepsi dengan kejadian kanker serviks menunjukkan nilai $\mathrm{p}=0,848$. Sehingga dapat disimpulkan bahwa Ho diterima yang artinya tidak ada pengaruh yang signifikan antara lama pemakaian alat kontrasepsi dengan kejadian kanker serviks. Hasil ini berdasarkan dari 109 dari 303 pasien yang terkena peradangan kanker serviks (erosi) dimana mayoritas pasien meggunakan alat kontrasepsi dengan lama kurang dari sama dengan 5 tahun yaitu 190 pasien.

Berdasarkan hasil penelitian membuktikan bahwa tidak ada pengaruh yang signifikan antara lama pemakaian alat kontrasepsi dengan kejadian kanker serviks. Hasil ini tidak sesuai dengan penelitian yang menyatakan bahwa pemakaian alat kontrasepsi lebih dari 5 tahun secara rutin dapat meningkatkan risiko terjadinya kanker serviks karena dapat menyebabkan infeksi pada leher rahim (Yunita, 2009).

Hubungan Antara Usia Perkawinan Pertama dengan Kejadian Kanker Serviks

Hasil penelitian mengenai hubungan usia perkawinan pertama dengan kejadian kanker serviks menunjukkan nilai $\mathrm{p}=$ 0,000. Sehingga dapat disimpulkan bahwa Ho ditolak yang artinya ada pengaruh yang signifikan atara usia perkawinan pertama dengan kejadian kanker serviks. Hal ini berdasarkan dari 109 dari 303 pasien yang terkena peradangan kanker serviks atau erosi dimana mayoritas pasien memiliki usia perkawinan pertama kurang dari sama dengan 22 tahun yaitu sebanyak 161 pasien.

Hasil mengenai penelitian ini yang menyatakan bahwa terdapat pengaruh yang signifikan antara usia perkawinan pertama 
dengan kejadian kanker serviks cocok dengan penelitian yang dilakukan oleh (Harianti, et al. 2015) tentang hubungan pernikahan muda dengan kejadian kanker serviks yang mengatakan bahwa penderita kanker serviks lebih banyak terjadi pada wanita yang melakukan pernikahan muda daripada wanita yang tidak menikah muda. Diketahui bahwa 58,0\% wanita menikah muda terkena kanker serviks. Penelitian ini memperoleh nilai $\mathrm{p}=0,041$ yang artinya Ho ditolak berarti dapat disimpulkan bahwa ada hubungan yang signifikan antara menikah muda dengan kejadian kanker serviks.

Hasil tersebut sesuai dengan teori yang mengatakan bahwa pada saat wanita berusia kurang dari 20 tahun mengalami perubahan sel pada mulut rahim, pada saat sel membelah secara aktif, benda asing seperti alat kelamin laki-laki dan sel sperma dapat memicu terjadinya kanker serviks karena perkembangan sel yang menjadi abnormal. Hal ini dapat terjadi ketika wanita menikah pada usia dini dan melakukan hubungan seksual ketika organ reproduksi yang belum matang. Ketika organ reproduksi belum sempurna dapat menimbulkan lesi saat melakukan hubungan seksual dan memicu virus HPV yang menjadi penyebab kanker serviks lebih mudah masuk dan menginfeksi organ intim wanita sehingga berkembang menjadi sel kanker di kemudian hari (Komalasari dan Andriyantoro, 2012).

\section{Hubungan Antara Usia Pasien dengan Kejadian Kanker Serviks}

Hasil penelitian mengenai hubungan antara usia pasien dengan kejadian kanker serviks memiliki nilai $\mathrm{p}$ sebesar 0,494 sehingga dapat disimpulkan bahwa Ho diterima yang artinya tidak ada pengaruh yang signifikan antara usia pasien dengan kejadian kanker serviks. Hal ini berdasarkan dari 109 dari 303 pasien yang terkena peradangan kanker serviks atau erosi dimana mayoritas pasien dengan usia kurang dari sama dengan 40 tahun yaitu sebesar 159 pasien.

Hal tersebut sesuai dengan hasil penelitian lain mengenai faktor-faktor yang berhubungan dengan kejadian kanker serviks pada wanita di rumah sakit umum daerah karawang tahun 2014. Penelitian tersebut menghasilkan sebanyak 85 orang yang berusia $>35$ tahun terkena kanker serviks. Sedangkan 6 orang yang berusia $\leq$ 35 tahun tidak menderita kanker serviks. Penelitian ini menghasilkan nilai $\mathrm{p}=1,000$ $>0,05$ yang artinya tidak ada pengaruh yang signifikan antara usia dengan kejadian kanker serviks (Saputra, 2015).

\section{Hubungan Antara Jenis Kontrasepsi dengan Kejadian Kanker Serviks}

Hasil penelitian mengenai hubungan antara jenis kontrasepsi yang digunakan dengan kejadian kanker serviks memiliki nilai $p$ sebesar 0,000 sehingga dapat disimpulkan bahwa Ho ditolak yang artinya ada pengaruh yang signifikan antara jenis alat kontrasepsi yang digunakan dengan kejadian kanker serviks. Hal ini berdasarkan dari 109 dari 303 pasien yang terkena peradangan kanker serviks atau erosi dimana mayoritas pasien menggunakan alat kontrasepsi berjenis hormonal yaitu sebesar 229 pasien.

Hasil penelitian ini sejalan dengan hasil penelitian dengan metode kasus kontrol mengenai hubungan pemakaian kontrasepsi hormonal dan hormonal dengan kejadian kanker serviks. Penelitian ini menggunakan 42 sampel kasus dan kontrol dan menghasilkan dari 21 orang yang memakai alat kontrasepsi hormonal 18 orang terkena kanker serviks dan 3 orang tidak terkena. Sedangkan pada 21 orang yang memakai jenis kontrasepsi non hormonal, 2 orang terkena kanker serviks dan 19 orang tidak terkena kanker serviks. Penelitian ini menghasilkan nilai $\mathrm{p}=0,00<0,05$ artinya pemakaian jenis alat kontrasepsi mempunyai pengaruh yang signifikan terhadap kejadian kanker serviks (Abdullah, et al. 2013).

\section{Hubungan Antara Jumlah Anak dengan Kejadian Kanker Serviks}

Hasil penelitian mengenai hubungan antara jumlah anak dengan kejadian kanker serviks memiliki nilai $p$ sebesar 0,565 sehingga dapat disimpulkan bahwa Ho diterima yang artinya tidak ada pengaruh yang signifikan antara jumlah anak dengan kejadian kanker serviks. Hal ini 
berdasarkan dari 109 dari 303 pasien yang terkena peradangan kanker serviks atau erosi dimana mayoritas pasien dengan jumlah anak kurang dari sama dengan 2 anak yaitu sebesar 184 pasien.

Hasil dari penelitian ini tidak sesuai dengan penelitian yang dilakukan oleh (Khoirunnisa dan Wulandari, 2013) tentang hubungan pernikahan usia dini, paritas, dan pemakaian kontrasepsi hormonal dengan kejadian kanker serviks yang menyatakan bahwa terdapat hubungan yang signifikan antara paritas dan kejadian kanker serviks dimana dari 74 wanita yang memiliki riwayat paritas lebih dari sama dengan 3 anak, ada 54 wanita yang menderita kanker serviks $(73,0 \%)$ dan sisanya yaitu 20 wanita tidak menderita kanker serviks $(27,0 \%)$.

Penelitian yang dilakukan oleh (Prandana dan Rusda, 2013) tentang Pasien Kanker Serviks di RSUP H. Adam Malik Medan yang mengatakan bahwa penderita kanker serviks dengan paritas paling banyak ditemukan antara 3-5 anak yaitu sebesar 206 pasien, sehingga dapat diketahui bahwa wanita yang sering melahirkan anak dengan jarak kelahiran yang terlalu pendek akan meningkatkan risiko terkena kanker serviks begitu pula dengan salah satu penelitian yang menyatakan bahwa penderita kanker serviks terbanyak adalah wanita yang memiliki kelahiran lebih dari 6 kali yaitu sebesar 58,7\%.

Penelitian ini tidak sesuai dengan penelitian sebelumnya dikarenakan data yang ada mengenai jumlah anak di yayasan kanker wisnuwardhana Surabaya mayoritas memiliki anak dibawah 2 anak yaitu sebesar 184 dengan keadaan serviks tenang sebanyak 116, sedangkan untuk keadaan serviks erosi pada wanita yang memiliki jumlah anak diatas 2 hanya sebanyak 41 pasien dari jumlah 119 pasien. Untuk itu hasil penelitian mengatakan bahwa jumlah anak tidak berpengaruh secara signifikan terhadap kejadian kanker serviks di yayasan kanker wisnuwardhana Surabaya.

\section{SIMPULAN DAN SARAN}

\section{Simpulan}

Hasil analisis yang telah dilakukan dapat disimpulkan bahwa analisis faktor risiko yang mempengaruhi kejadian kankerserviks di YayasanKankerWisnuwardhana Surabaya tahun 2015 dengan menggunakan metode regresi logistik biner menghasilkanterdapat 3 variabel independen yang signifikan, yaitu variabel

kunjunganpemeriksaanpapsmear, usiapernikahanpertama, danjenisalatkontrasepsi.Model regresi logistik biner yang terbentuk telah sesuai sehingga mampu memprediksi nilai observasinya.

\section{Saran}

Dinas kesehatan lebih banyak melakukan edukasi kepada kelompok wanita yang rentan terhadap kanker serviks melalui media leaflet atau poster tentang bahaya kanker serviks sehingga masyarakat dapat mengerti dan melakukan pencegahan dini dengan melakukan pemeriksaan papsmear untuk upaya preventif.

Perlu mensosialisasikan cara menentukan pilihan alat kontrasepsi yang rasional kepada pasangan usia subur yang belum mengikuti program Keluarga Berencana (KB). Selain itu juga perlu untuk meningkatkan kesadaran masyarakat terhadap program KB yang ada antara lain dengan meningkatkan jaringan komunikasi yang sudah ada.

Dinas kesehatan membentuk kader yang dapat memberikan bimbingan atau pengetahuan kepada orang tua serta anak yang belum menikah tentang bahaya kanker serviks jika menikah pada usia muda dan juga membatasi pergaulan bebas khususnya terhadap wanita.

\section{DAFTAR PUSTAKA}

Abdullah, S., Bawotong, J., Hamel, R., 2013. Hubungan Pemakaian Kontrasepsi Hormonal dan Hormonal Dengan Kejadian Kanker Serviks di Ruang D Atas BLU, PROF, Dr, R. D. 
Kandou, Manado. E-Jurnal

Keperawatan, 1(1): pp. 2-7.

Asyiah, N., 2008. Regresi Logistik dan

Penerapannya Dalam Bidang

Kesehatan (Studi Kasus Kelahiran

Prematur di RSKIA Muhammadiyah

Kotagede Yogyakarta). Skripsi.

Universitas Islam Negeri Sunan

Kalijaga.

Aziz., Farid, M., 2002 Deteksi Dini

Kanker, Skrinning dan Deteksi Dini

Kanker Serviks : ed Ramli Muchils, Umbas Rainy, Panigoro S.Sonar.

Jakarta: Fakultas Kedokteran

Universitas.

Centers for Disease Control and

Prevention. 2013. Gynecologic

Cancer: CervicalCancer Prevention.

Tersedia di:

http://www.cdc.gov/cancer/cervical/ba

sic info/prevention.htm [14 Maret 2016].

Dewi, N.K., Rejeki, S., Istiana, S., 2015.

Hubungan Lama Penggunaan

Kontrasepsi Oral Pada Wanita Usia

Lebih Dari 35 Tahun Dengan Stadium

Kanker Serviks di RSUD Kota

Semarang. Jurnal Kebidanan, 4(1):

pp.31-38.

Fitriana, N.A., Ambarini, T.K., 2012.

Kualitas Hidup Pada Penderita Kanker

Serviks Yang Menjalani Pengobatan

Radioterapi. Jurnal Psikologi Klinis

dan Kesehatan Mental, 1(2): pp.123129.

Harahap E. Ruslan, 1997. Neoplasia Intra Epitel (NIS) pada Serviks. UI Press Jakarta.

Hosmer D.W., Lemeshow S. 2000. Applied Logistic Regression. Edisi 2. New

York : John Wiley and Sons.

Indrayani, D., 2007. Pengalaman Hidup

Klien Kanker Serviks di Bandung.

Skripsi. Fakultas Ilmu Keperawatan

Universitas Padjajaran.

Jasaputra, D.K., Santosa, S. Metodologi

Penelitian Biomedis. Edisi 2.

Bandung: PT. Danamartha Sejahtera Utama.

Lasut, E., Rarung, M., Suparman, E., 2015.

Karakteristik Penderita Kanker

Serviks di BLU RSUP PROF. DR. R.
D. Kandou. Jurnal e-Clinic (eCl), 3(1): pp.83-86.

Lemeshow, S., Hosmer, D.W., Klar, J., Stephen K.L., 2003. Adequancy Of Sample Size In Health Studies. WHO.

Mardjikoen, P. 2007. Tumor Ganas Alat

Genital. Jakarta : Yayasan Bina

Pustaka Sarwono Prawirohardjo.

Murti, Bhisma. 2001. Prinsip dan Metode

Riset Epidemiologi BAB III.

Yogyakarta : Gadjah Mada University Press.

National Cancer Institute. 2012. Cervical C ancer Prevention. Tersedia di:

http://www.cancer.gov/cancertopics/p $\mathrm{dq} /$ prevention/cervical/Patient/page3 [ 14 Maret 2016].

Norusis MJ. 2010. SPSS Statistics Guides: Ordinal Regression. Tersedia di: http://www.norusis.com/pdf/ASPC_v1 3.pdf [3 Juni 2016].

Nugrahani, R.M., Salamah, M., 2012. Analisis Faktor-Faktor yang Mempengaruhi Hasil Pap Test Kanker Serviks Dengan Menggunakan Metode Regresi Logistik Ordinal (Studi Kasus Pasien di Rumah Sakit "X" Surabaya). Jurnal Sains dan Seni ITS, 1(1): pp.1619.

Prandana, D.A., Rusda, M., 2013. Pasien Kanker Serviks di RSUP H. Adam Malik Medan Tahun 2011. E-Jurnal FK USU, 1(2): pp.731

Saputra, S., 2015. Faktor-faktor Yang Berhubungan Dengan Kejadian Kanker Serviks Pada Wanita di Rumah Sakit Umum Daerah Karawang Tahun 2014. Jurnal Ilmiah Keperawatan STIKes Medika Cikarang, 5(1): pp.18-27.

Septadina, I.S., Kesuma, H., Handayani,

D., Suciati, T., Liana, P., 2015.

UpayaPencegahan Kanker Serviks

Melalui Peningkatan Pengetahuan

Kesehatan Reproduksi Wanita dan

Pemeriksaan Metode IV A (Inspeksi

Visual Asam Asetat) di Wilayah Kerja

Puskesmas Kenten Palembang. Jurnal

Pengabdian Sriwijaya.

Wahyuningsih, T., Mulyani, E.Y., 2014.

Faktor Risiko Terjadinya Lesi

Prakanker Serviks Melalui Deteksi

Dini Dengan Metode IV A (Inspeksi 
Faktor Pengaruh Kejadian Kanker Serviks Di Yayasan Kanker .. | DESSYAR PATRICIA

Visual Dengan Asam Asetat). Forum

Ilmiah, 11(2): pp.192-209.

Yakub, MY, 1993 Tinjauan Kusus

Penderita Kanker Leher Rahim yang

Dirawat di Rumah Sakit Umum Pirngadi

Medan Periode 1 Januari 19-31 Desember

1990. Thesis. Universitas Sumatra Utara. 
JURNAL ILMIAH KESEHATAN MEDIAHUSADA ｜ VOLUME 06/NOMOR 01/MARET 2017 